\title{
A Short Review on Ethnomedicinal Uses and Phytochemistry of Silybum marianum
}

Nooren Zahra*

Department of Botany, University of Agriculture, Faisalabad, Pakistan

*Corresponding author: Nooren Zahra, Department of Botany, University of Agriculture, Faisalabad, Pakistan, Tel: 03016096956; E-mail: noreenzahra59@yahoo.com

Received: September 01, 2017; Accepted: September 14, 2017; Published: September 20, 2017

Copyright: (C) 2017 Zahra N. This is an open-access article distributed under the terms of the Creative Commons Attribution License, which permits unrestricted use, distribution, and reproduction in any medium, provided the original author and source are credited.

\begin{abstract}
Herbs have been used permanently as the major source of medicine. Medicinal plants are important by secondary metabolites such as Silymarin, it is a mixture of flavonoids. Silybum marianum is a safe herb, rare reactions were reported if the dosage is high. There are medical confirmations for anticarcinogenic and hepatoprotective activities of Milk thistle. Silybum marianum is used vigorously in cirrhosis, prostate, skin and breast cancer, cervical cells and kidney ailments. This review is about the Phytochemistry and Ethnomedicinal uses of Silybum marianum.
\end{abstract}

Keywords: Silybum marianum; Hepatoprotective; Anticarcinogenic; Cirrhosis; Ethnomedicinal phytochemistry

\section{Introduction}

Plants are a valuable source of nutrition, food, flavors, fiber, pigments, pharmaceuticals, Agrochemicals, insecticides. These are secondary compounds present in taxonomic groups, these compounds are only important for the ecological interactions not useful for the survival of these plants [1]. Silybum marianum (L.) Gaertn common name is milk thistle, it is an edible plant belongs to the Asteraceae family. Four different isomers were isolated from its secondary compound silymarin (silidianin isosilibinin, silibinin and silichristin) [2]. Milk thistle is hepatoprotectants for cancer Patients. Toleration of cancer therapy may progress from using this herb, reason is that it is blood and liver toxin clearing agents [3]. It has strong anticancer effects against breast, tumors, ectocervical and prostate [4]. Against the ovarian cancer, it enhanced the effectiveness of doxorubicin and cisplatin in vitro experiment [5]. Silybum marianum, has been used safely for children [6], older [7] and pregnant women [8]. It is used in cholestatic, etiologies, viral, alcoholic and toxic effect removing medicines [9].

\section{Morphological characters}

Milk thistle, is a tall plant having milky white veins, dark green leaves, thorns on the stems, and purple flower [10]. Milk thistle has ability to achieve a height of $2 \mathrm{~m}$ with spiny edges leaves [11]. Solitary inflorescences and at the apex large heads are positioned with branches. The florets are tubular, hermaphrodite having purple, red or white color [12]. Milk thistle is mostly self-pollinator [13]. Milk thistle pollen grain shape is prolate when looks at equatorial region and seems semi angular in polar sight [14]. The seeds have white pappus brownish in color, shiny, taking hard skin achenes, mainly six to eight milimolar long [15].

\section{Cytology of Silybum marianum}

Milk thistle has 34 diploid chromosomes. The karyotype arrangement shows that, ten pairs sub metacentric, six pairs metacentric and having only one single acrocentric chromosome (Table 1) [16].

\section{Systematic position}

\begin{tabular}{|l|l|}
\hline Kingdom & Plantae \\
\hline Order & Asterales \\
\hline Family & Asteraceae \\
\hline Tribe & Cynareae \\
\hline Genus & Silybum \\
\hline Species & S. marianum \\
\hline
\end{tabular}

Table 1: Botanical name: Silybum marianum(L.) Gaertn.

\section{Distribution and habitat}

Milk thistle native of the Mediterranean region and which has also spread in East Asia, Europe, and, Australia and America [17]. It is commonly found in cereal crops [18]. Waste places [19], waysides [20]. Moreover, Milk thistle has an eye-catching leaf pattern so grown as decorative purposes [21]. Milk thistle can grow predominately on sandy soils and denser clay soils. It is requires row spacing $40-75 \mathrm{~cm}$, and in between plants $20-30 \mathrm{~cm}$. Sowing season is spring and autumn. Milk thistle can grow in different conditions with low or poor nutrient and soil requirements. Weeds interfere with milk thistle production. Milk thistle can grow in low water supply [22].

\section{Widespread uses}

Since the first century Milk thistle has been used medicinally [23]. Its flowers, leaves and roots have been used as European diets as vegetable, and its achene is used as a coffee. It considered as a spinach substitute. The flower head is used for medicine. It is used as a remedy for Amanita mushroom toxins [24]. 


\section{Ethno botany}

Silymarin and silybin helpful for fighting against hepatotoxins such as toluene, alcohol, tetrachloromethane, xylene and carbon tetrachloride [25]. Hepatoprotective by cell membranes stabilizing, increasing DNA polymerase activity [26] and act as antioxidant [27]. Silybin acted as a stimulating agent for DNA polymerase reactions, cell regeneration of liver and ribosomal RNA; Silybin regulated the production of free radicals, increasing glutathione peroxidase and superoxide dismutase, so stabilizing membranes and increased the glutathione in liver and human cell lines [28,29]. It also controls the liver inflammation by repressing the pathway of 5-lipoxygenase. Inhibition of hepatocytes and amatoxin by Slimarin was discovered in vitro [30,31]. Milk thistle used for alcoholic liver damage, alcoholic induced liver diseases [32]. Used against diabetes mellitus disease [33].

Silymarine have hypocholesterolaemic activity [34] and hypertensive activity by reducing heartbeat, systolic basal and arterial blood pressure [35]. In culture nerve growth factor prompted neurite outgrowth was observed by milk thistle application [36]. In cervical, prostate and breast cancer milk thistle control the cell division and DNA synthesis [37]. Milk thistle fight against viral infection, inflammation and cytotoxicity [38].

\section{Antioxidant}

Silymarin are recognized as effective antioxidants [39]. Silybin repressed peroxidation in vitro [34]. In human inhibited the malondialdehyde [38], hydrogen peroxide [40], lipid peroxidation induced by chemicals [41]. Silymarin used as an antioxidant against gastric ulcer disease [42].

\section{Phytochemistry}

The pharmacological compound is Silymarin has flavolignans silychristin, quercetin, isosilybin, silybonol, silybin, betaine, taxifolin and silydianin $[42,43]$. The highest concentration of Silymarin is found in the fruit. Other ingredients are fixed oils, amines, betaine and trimethylglycine and. Milk thistle seed contains flavone lignans, fixed oil, oleic acid, palmitic acid, protein, tocopherol, sterols; contain cholesterol, mucilage, sitosterol, campesterol and stigmasterol [44].

\section{Antiviral activity}

Silybin have antiviral and antifibrotic activities [45] antiproliferative [46] and immunomodulatory actions [47]. Moreover, Milk thistle control the production of HCV infection through, stopping the virus transmission [48] and RNA polymerase activity. Also inhibiting viral fusion, viral entry and controlling viral protein and RNA synthesis [46].

\section{Conclusion}

This article briefly reviews the ethnobotany and phytochemistry of milk thistle. The plant are widely used in pharmaceutical industries and also preferred in traditional medicines. This is an effort to assemble and file the material on diverse features of $S$. marianum. This review is imoratnt for the further research in future.

\section{References}

1. Verpoorte R, Alfermann AW (2000) Metabolic Engineering of Plant Secondary Metabolism. Kluwer Academic Publishers, The Netherlands.
2. Lee DY, Liu Y (2003) Molecular structure and stereochemistry of silybin A, silybin B, isosilybin A and isosilybin B, isolated from Silybum marianum (milk thistle). J Nat Prod 66: 1171-1174.

3. Ladas EJ, Cheng B, Hughes D (2006) Milk thistle (Silybum marianum) is associated with reductions in liver function tests (LFTs) in children undergoing therapy for acute lymphoblastic leukemia (ALL). Society of Integrative Oncology, Boston, Mass.

4. Bhatia N, Zhao J, Wolf DM (1999) Inhibition of human carcinoma cell growth and DNA synthesis by silibinin, an active constituent of milk thistle: comparison with silymarin. Cancer Lett 147: 77-84.

5. Duthie SJ, Johnson W, Dobson VL (1997) The effect of dietary flavonoids on DNA damage (strand breaks and oxidised pyrimdines) and growth in human cells. Mutat Res 390: 141-151.

6. Allain H, Schück S, Lebreton S (1999) Aminotransferase levels and silymarin in de novo tacrine-treated patients with Alzheimer's disease. Dementia Geriatr Cogn Disord 10: 181-185.

7. Hernandez R, Nazar E (1982) Effect of silymarin in intrahepatic cholestasis of pregnancy. Ethiopia 47: 22-29.

8. Greenlee H, Abascal K, Yarnell E, Ladas E (2007) Clinical applications of Silybum marianum in oncology. Integr Cancer Ther 6: 158-165.

9. Eliss RH, Covell S, Roberts EH, Sumerfield RG (1986) The influence of temperature on seed germination rate in grain legumes. II. Interspecific variation in chickpea (Cicer arietinum L.) at temperature. J Exp Bot 37: 1503-1515.

10. Carrier DJ, Crowe T, Sokhansanj S, Wahab J, Barl B (2003) Milk Thistle, Silybum marianum (L.) Gaertn, flower head development and associated marker compound profile. J Herbs Spices Med Plants 10: 65-74.

11. Vaknin Y, Hadas R, Schafferman D, Murkhovsky L, Bashan N (2008) The potential of milk thistle (Silybum marianum L.), an Israeli native, as a source of edible sprouts rich in antioxidants. Int J Food Sci Nutr 9: 339-346.

12. Hetz E, Liersch R, Schieder O (1995) Genetic investigations on Silybum marianum and S. eburneum with respect to leaf colour, outcrossing ratio, and flavonolignan composition. Planta Medic 61: 54-57.

13. Ahmad M, Khan MA, Hasan A, Zafar M, Sultana S (2008) Chemotaxonomic standardization of herbal drugs milk thistle and globe thistle. Asian J Chem 20: 4443-4459.

14. Corchete P (2008) Silybum marianum (L.) Gaertn: the source of silymarin. In: Ramawat KG, Merillon JM, (eds.), Bioactive Molecules and Medicinal Plants. Springer, pp: 123-148.

15. Asghari-Zakaria R, Panahi AR, Sadeghizadeh M (2008) Comparative study of chromosome morphology in Silybum marianum. Cytol 73: 327-332.

16. Montemurro P, Fracchiolla M, Lonigro A (2007) Effects of some environmental factors on seed germination and spreading potential of Silybum marianum Gaertner. Ital J Agron 3: 315-320.

17. Veres T, Tyr S (2012) Milk thistle (Silybum marianum (L.) Gaertn.) as a weed in sustainable crop rotation. Res J Agric Sci 44: 118-122.

18. Gabay R, Plitmann U, Danin A (1994) Factors affecting the dominance of Silybum marianum L. (Asteraceae) in its specific habitats. Flora 189: 201-206.

19. Karkanis A, Bilalis D, Efthimiadou A (2011) Cultivation of milk thistle (Silybum marianum L. Gaertn.), a medicinal weed. Ind Crops Prod 34: 825-830.

20. Bhattacharya S (2011) Phytotherapeutic properties of milk thistle seeds: An overview. J Adv Pharm Educ Res 1: 69-79.

21. Luper S (1998) A review of plants used in the treatment of liver disease. Altern Med Rev 3: 410-421.

22. Flora K, Hahn M, Rosen H, Benner K (1998) Milk thistle (Silybum marianum) for the therapy of liver disease. Am J Gastroenterol 93: 139-143.

23. Tuchweber B, Sieck R, Trost W (1979) Prevention of silybin of phalloidininduced acute hepatoxicity. Toxicol Appl Pharmacol 51: 265-275.

24. Robbers JE, Tyler VE (1999) Tyler's Herbs of choice: the therapeutic use of phytomedicinals. New York: Haworth Herbal Press, p: 287. 
Citation: Zahra N (2017) A Short Review on Ethnomedicinal Uses and Phytochemistry of Silybum marianum . Nat Prod Chem Res 5: 292. doi: $10.4172 / 2329-6836.1000292$

Page 3 of 3

25. Fiebrich F, Koch H (1979) Silymarin, an inhibitor of lipoxygenase. Experiment 35: 1548-1560.

26. Valenzuela A, Guerra R (1985) Protective effect of the flavonoid silybin dihemisuccinate on the toxicity of phenylhydrazine on rat liver. FEBS Lett 181: 291-294.

27. Faulstich H, Jahn W, Wieland T (1980) Silybin inhibition of amatoxin uptake in the perfused rat liver. Arzneimittelforschung 30: 452-454.

28. Bosisio E, Benelli C, Pirola O (1992) Effect of the flavanolignans of Silybum marianum L. on lipid perocidation in rat liver microsimes and freshly issolated hepatocytes. Pharmacol Res 25: 147-154.

29. Deak G, Muzes G, Land I, Niederland V, Kristof N, et al. (1990) Immunomodulatory effects of silymarin treatment in chronic alcoholic liver disease. Orvosi Hetilap 131: 1291-1296.

30. Soto CP, Perez BL, Favari LP, Reyes JL (1998) Prevention of alloxaninduced diabetes mellitus in the rat by silymarin. Compar Pharmaco Toxicol 119: 125-129.

31. Haddad Y, Vallerand D, Brault A, Haddad PS (2009) Antioxidant and hepatoprotective effects of silibinin in a rat model of nonalcoholic steatohepatitis. Hindawi Publications.

32. Skottova N, Krecman V (1998) Silymarin as a potential hypocholesterolaemic drug. Physiol Res 47: 1-7.

33. Jadhav GB, Upasani CD (2011) Antihypertensive effect of Silymarin on DOCA salt induced hypertension in unilateral nephrectomized rats. Orient Pharm Exp Med 11: 101-106.

34. Dehmlow C, Erhard J, De Groot H (1996) Inhibition of Kupffer cell functions as an explanation for the hepatoprotective properties of silibinin. Hepatol 23: 749-754.

35. Kittur S, Wilasrusmee S, Pedersen WA (2002) Neurotrophic and neuroprotective effects of milk thistle (Silybum marianum) onneurons in culture. J Mol Neurosci 18: 265-269.

36. Bhatia N, Zhao J, Wolf DM, Agarwal R (1999) Inhibition of human carcinoma cell growth and DNA synthesis by silibinin, an active constituent of milk thistle: comparison with silymarin. Canc Lett 147: 77-84.

37. Wenzel S, Stolte H, Soose M (1996) Effects of silibinin and antioxidants on high glucose-induced alterations of fibronectin turnover in human mesangial cell cultures. J Pharmacol Exp Ther 279: 1520-1526.
38. Anderson D, Yu TW, Phillips BJ, Schmezer P (1994) The effect of various antioxidants and other modifying agents on oxygen-radical-generated DNA damage in human lymphocytes in the COMET assay. Mutat Res 307: 261-271.

39. Carini R, Comoglio A, Albano E, Poli G (1992) Lipid peroxidation and irreversible damage in the rat hepatocyte model. Protection by the silybin-phospholipid complex IdB 1016. Biochem Pharmacol 43: 2111-2115.

40. Alarcon DeLaLastra C, Martin MJ, Motilva V, Jimenez M, LaCasa C, et al. (1995) Gastroprotection induced by silymarin, the hepatoprotective principle of Silybum marianum in ischemia-reperfusion mucosal injury: Role of neutrophils. Planta Medica 61: 116-119.

41. Weyhenmeyer R, Mascher H, Birkmayer J (1992) Study on dose-linearity of the pharmacokinetics of silibinin diastereomers using a new stereospecific assay. Int J Clin Pharmacol Ther Toxicol 30: 134-138.

42. Kren V, Walterova D (2005) Silybin and silymarin-New effects and applications. Biomed Papers 149: 29-41.

43. https://www.mdidea.com/products/herbextract/silymarin/data.html

44. Agarwal R, Agarwal C, Ichikawa H, Singh RP, Aggarwal BB (2006) Anticancer potential of silymarin: from bench to bed side. Anticancer Res 26: $4457-4498$

45. Polyak SJ, Morishima C, Lohmann V, Pal S, Lee DY, et al. (2010) Identification of hepatoprotective flavonolignans from silymarin. Proc Natl Acad Sci 107: 5995-5999.

46. Polyak SJ, Morishima C, Shuhart MC, Wang CC, Liu Y, et al. (2007) Inhibition of T-cell inflammatory cytokines, hepatocyte NF-kappaB signaling, and HCV infection by standardized Silymarin. Gastroenterol 132: 1925-1936.

47. Wagoner J, Morishima C, Graf TN, Oberlies NH, Teissier E, et al. (2011) Differential in vitro effects of intravenous versus oral formulations of silibinin on the HCV life cycle and inflammation. PLoS ONE 6: e16464.

48. Morishima C, Shuhart MC, Wang CC, Paschal DM, Apodaca MC, et al. (2010) Silymarin inhibits in vitro T-cell proliferation and cytokine production in hepatitis C virus infection. Gastroenterol 138: 671-681. 